\title{
Evaluation of Fall Chinook Salmon Spawning Adjacent to the In-Situ Redox Manipulation Treatability Test Site, Hanford Site, Washington
}

R. P. Mueller

D. R. Geist

October 1998

Prepared for

the U.S. Department of Energy

under Contract DE-AC06-76RLO 1830

This work is funded by the Office of Science and Technology, within the Department of Energy's Office of Environmental Management, under the Subsurface Contaminants Focus Area

Pacific Northwest National Laboratory

Richland, Washington 99352 


\section{DISCLAIMER}

This report was prepared as an account of work sponsored by an agency of the United States Government. Neither the United States Government nor any agency thereof, nor any of their employees, makes any warranty, express or implied, or assumes any legal liability or responsibility for the accuracy, completeness, or usefulness of any information, apparatus, product, or process disclosed, or represents that its use would not infringe privately owned rights. Reference herein to any specific commercial product, process, or service by trade name, trademark, manufacturer, or otherwise does not necessarily constitute or imply its endorsement, recommendation, or favoring by the United States Government or any agency thereof. The views and opinions of authors expressed herein do not necessarily state or reflect those of the United States Government or any agency thereof. 


\section{DISCLAIMER}

Portions of this document may be illegible in electronic image products. Images are produced from the best available original document. 


\section{Executive Summary}

The In Situ Redox Manipulation (ISRM) experiment is being evaluated as a potential method to remove contaminants from groundwater adjacent to the Columbia River near the 100-D Area. The ISRM experiment involves using sodium dithionate $\left(\mathrm{Na}_{2} \mathrm{O}_{6} \mathrm{~S}_{2}\right)$ to precipitate chromate from the groundwater. The treatment will likely create anoxic conditions in the groundwater down-gradient of the ISRM treatability test site; however, the spatial extent of this anoxic plume is not exactly known.

The ISRM experiment was reviewed by the American Society of Mechanical Engineers (ASME) Peer Review Committee, which expressed concern over the possible impacts of anoxic groundwater on fall chinook salmon (Oncoryhynchus tshawytscha) that spawn in the vicinity of the 100-D Area. Aerial spawning surveys have documented fall chinook salmon spawning near the island approximately $250 \mathrm{~m}$ downstream of the 100-D Area (river kilometer 615), but not specifically in the vicinity of where the groundwater plume is projected to intersect the river. Aerial surveys are limited in their ability to located redds in water depths greater than $4 \mathrm{~m}$, and a portion of the river adjacent to the ISRM experiment exceeds $4 \mathrm{~m}$ in depth. Therefore, an underwater video survey was conducted to detect any fall chinook salmon spawning and/or suitable spawning habitat in the area where the groundwater plume is projected to enter the Columbia River.

Surveys were conducted in November 1997, following the peak spawning of fall chinook salmon. Aerial surveys documented 210 redds (spawning nests) near the downstream island in locations consistent with previous surveys. Neither aerial nor underwater surveys documented fall chinook spawning in the vicinity of the ISRM treatability test site. Based on measurements of depth, velocity, and substrate, less than $1 \%$ of the study area contained suitable fall chinook salmon spawning habitat, indicating low potential for fall chinook salmon to spawn in the vicinity of the ISRM experiment. 


\section{Acknowledgements}

This work was prepared with the support of the following contributors:

$\begin{array}{ll}\text { Headquarters: } & \begin{array}{c}\text { Office of Science and Technology } \\ \text { Skip Chamberlain }\end{array} \\ \text { Focus Area/Program: } & \begin{array}{c}\text { Subsurface Contaminants Focus Area } \\ \text { James Wright }\end{array} \\ \text { Operations Office: } & \begin{array}{l}\text { Richland Operations Office } \\ \text { Science and Technology Programs Division } \\ \text { John P. Neath, Technical Program Officer }\end{array} \\ \text { Contractor: } & \begin{array}{l}\text { Pacific Northwest National Laboratory } \\ \text { Environmental Science and Technology } \\ \text { Environmental Technology Division } \\ \text { Rod K. Quinn, Manager }\end{array}\end{array}$

The authors thank Bill Mavros, Jeff Marco, and Joanne Duncan for providing. valuable technical support and Dennis Dauble for reviewing earlier drafts of this report. 


\section{Contents}

Executive Summary ................................................................................. iii

Introduction ....................................................................................... 1

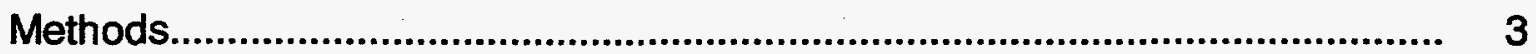

Results and Discussion ......................................................................... 9

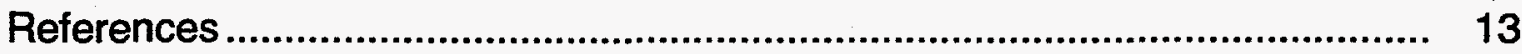

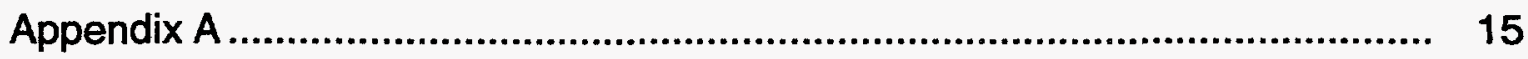

\section{Figures}

1 Map of study area and river transects in relation to ISRM treatability site and the 100-D reactor area current chromium concentration in groundwater...

2 Digitized substrate image showing laser reference marks. Distance between laser points is $18.4 \mathrm{~cm}$.

3 The distribution across categories of nose velocities, depth, dominant substrate, and subdominant substrate as a percentage of the total study area adjacent to the ISRM test site

4 The estimated distribution of suitable spawning habitat for fall chinook salmon at the ISRM test site.

Tables

1 Substrate categories used for spawning habitat classification

2 Preferred spawning habitat criteria for fall chinook salmon and our corresponding categories for dominant and subdominant substrate, nose velocity, and depth.

3 The estimated amounts of suitable spawning habitat for adult fall chinook salmon within the study site adjacent to the 100-D ISRM test site 


\section{Introduction}

The Hanford Reach is the last significant mainstem spawning area for fall chinook salmon (Oncoryhynchus tshawytscha) in the Columbia River Basin (Geist 1995; Dauble and Watson 1997) and represents a healthy population of the most inland fall chinook salmon stock in the Pacific Northwest and California (Huntington et al. 1996). Fall chinook salmon typically spawn within the Hanford Reach from October through December with peak spawning occurring in midNovember (Dauble and Watson 1997). The eggs remain in the gravel until early spring, and young rear in the reach for 2-3 months before migrating to the Pacific Ocean from May through August. Because of the length of time the eggs and fry are in the substrate and the fact that contaminated groundwater is hydraulically connected to the river via the substrate, this is the life stage most vulnerable to groundwater contamination (Geist et al. 1994).

Chromium concentrations in groundwater originating from the 100-D Area of the U.S. Department of Energy (DOE) Hanford Site exceed drinking water standards (DWS) (40 CFR 141-143 and Chapter 248-54 Washington Administrative Code) and ambient water quality criteria (EPA 1986). Hanford Site managers are concerned about the potential impact from chromium on the aquatic organisms in the Hanford Reach, including salmon populations, and various technologies are being investigated to remove chromium from groundwater before it reaches the river. One demonstration project involving groundwater treatment is the In Situ Redox Manipulation (ISRM) experiment, a pilot project using a water-permeable barrier to treat contamination plumes in place. In 1997, 14 wells were installed within the 100-D Area approximately 150 $\mathrm{m}$ from the Columbia River. The ISRM experiment involves injecting sodium dithionate $\left(\mathrm{NaO}_{6} \mathrm{~S}_{2}\right)$ into these wells to precipitate chromate from the groundwater and prevent it from entering the Columbia River. Following injection, the chromate is converted to an insoluble, immobile, and much less toxic 3 valent state.

The ISRM experiment is expected to reduce the amount of chromium that reaches the Columbia River. However, the treatment is also expected to create anoxic conditions in the groundwater, and it is not clear how far down-gradient of the ISRM treatability test site this anoxic groundwater plume will extend.

Because salmon eggs and newly emerged fry need well-oxygenated water in the substrate in order to survive, the ASME Peer Review Committee expressed concern over the possible impacts of this anoxic groundwater on fall chinook salmon that spawned in the vicinity of the 100-D Area. Dissolved gas tracer studies are being conducted to obtain more information on the re-oxygenation of the plume. 
Aerial surveys for fall chinook salmon spawning have been conducted in the Hanford Reach since 1943 (Dauble and Watson 1997). Historically very little spawning has occurred where the treated groundwater plume is expected to enter the Columbia River. However, up to 150 salmon spawning nests (redds) have been observed annually about $240 \mathrm{~m}$ downstream of the ISRM treatability site (river kilometer 615). Aerial surveys are limited in their ability to detect redds in water depth greater than $4 \mathrm{~m}$ (Dauble and Watson 1997). It was not known if the water depth in the river adjacent to the ISRM experiment exceeded $4 \mathrm{~m}$ or if redds were going undetected. Further, reviewers wondered if the habitat adjacent to the ISRM experiment was suitable for fall chinook salmon spawning.

In response to these concerns, Pacific Northwest National Laboratory (PNNL) conducted a mobile underwater video survey of the river adjacent to the ISRM experiment. Underwater video technology has been used for several years to characterize salmon spawning habitat (Dauble et al. 1994, 1995). This tool provides an effective technique for documenting salmon redds at deeper depths than can be observed from aerial surveys and provides a permanent video record of the area. The area we searched encompassed about $600 \mathrm{~m}$ of the Columbia River both upstream and downstream of the ISRM test site. The objective of this activity was to document any fall chinook salmon spawning that was not detected by aerial surveys and determine if suitable physical habitat characteristics existed for fall chinook spawning in the vicinity of the 100-D ISRM experiment. Aerial surveys were also conducted under a separate contract with DOE during October and November. 


\section{Methods}

Based on the projected plume gradient for the ISRM experiment, a study area was established that encompassed $316,000 \mathrm{~m}^{2}$ of the Columbia River bottom adjacent to the ISRM test site (Figure 1). Because exact locations of groundwater infiltration to the river bed were unknown, eleven transects were run perpendicular to the river flow at $61-\mathrm{m}$ intervals across the entire cross section of the river. The average transect length was $518 \mathrm{~m}$.

Underwater surveys of redds and characterization of potential spawning habitat (defined by water depth, substrate size, and water velocity) were conducted on November 11 and 13, 1997. The first survey involved collecting point water velocities near the river bed as well as velocity profiles along each transect. The second survey was dedicated to gathering substrate images and conducting a general search for redds in the area of influence.

An on-board, real-time global positioning system (GPS; Trimble Pathfinder ${ }^{\mathrm{TM}}$ Pro XR and ASPEN software) was used to collect positional data as well as to navigate a pre-set transect grid during the surveys. The integrated GPS beacon receiver and antenna provided GPS corrections for calculating submeter accuracy $(\sim 0.5 \mathrm{~m})$ on a second-by-second basis, and thus eliminated the use of a surveyor to capture positional information of the boat during surveys.

Longer data point acquisitions provided positions with $>0.5-\mathrm{m}$ accuracy. The ASPEN software displayed a background map of the study site on a notebook computer so that we could navigate to site locations on a predetermined transect line or visually verify data accuracy in the field.

The mobile underwater video system comprised a high-sensitivity remote camera. The video recording system consisted of high-resolution monochrome cameras (Sony, model HVM-352) with a wide-angle lens (110 $)$ connected to an 8-mm camcorder (Sony model CCD-FX710 Handycam Hi8). Recordings were made with Sony Hi8 tapes. Two high-resolution monitors were used during the surveys for better viewing of the video obtained by the remote camera. The location for each image (UTM X and UTM Y) was correlated to GPS location by a time stamp. 


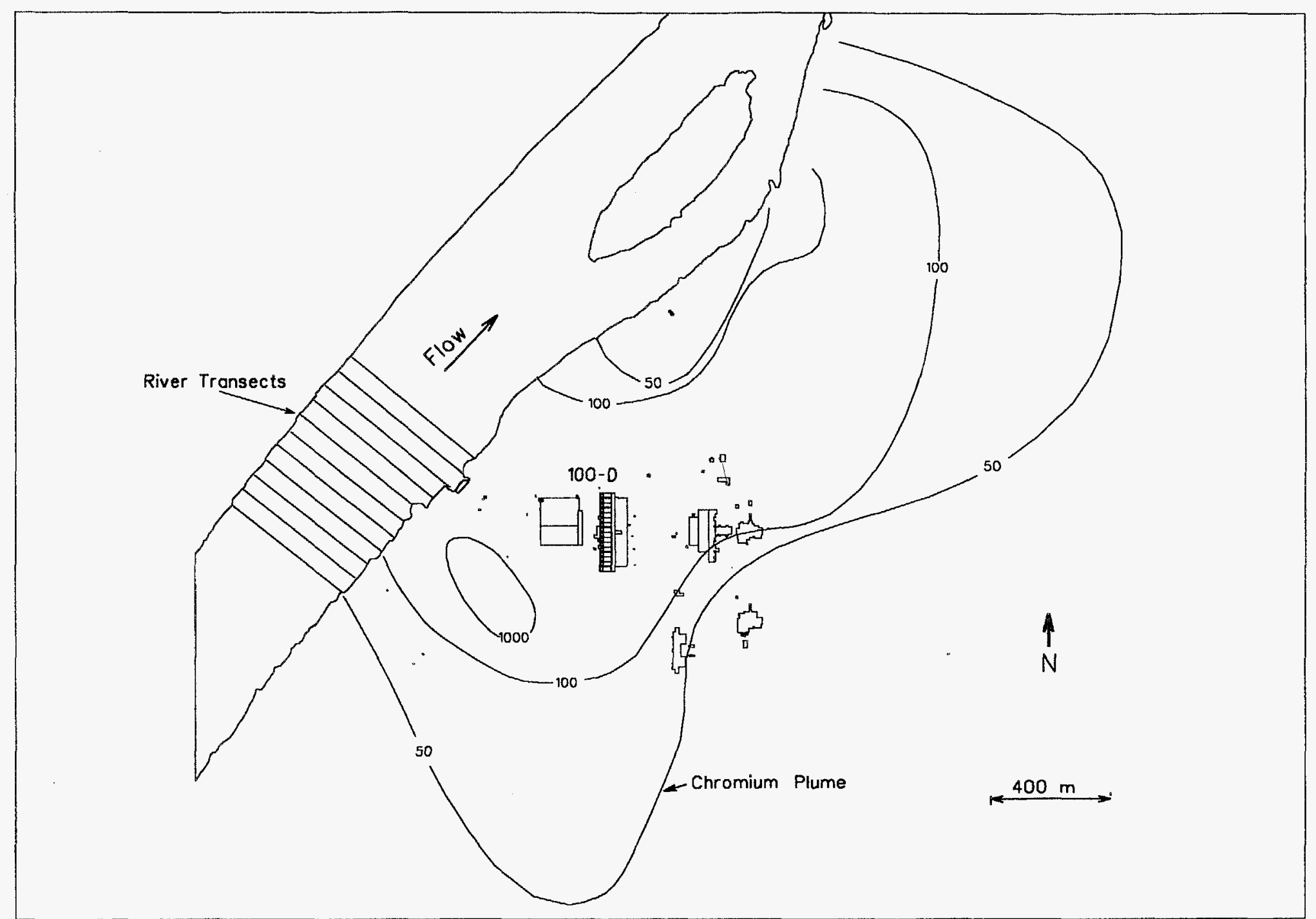

Figure 1. Map of study area and river transects in relation to ISRM treatability site and the 100-D reactor area current chromium concentration $(\mathrm{PPb})$ in groundwater 
The remote camera was mounted vertically on a diving sled platform deployed from a motorboat. Two lasers pointed downward $18.4 \mathrm{~cm}$ apart and were used to provide a reference scale within the camera image (Figure 2). The distance from the camera lens to the substratum ranged from 0.9 to $1.4 \mathrm{~m}$, providing an effective view path of $2.7 \mathrm{~m}^{2}$. The total area surveyed by underwater video was estimated to be $22,800 \mathrm{~m}^{2}$. Changes in background contrast, bed elevation, and substrate composition were the primary criteria used to determine spawning activity. Water depth at each substrate image was recorded using a depth finder.

Recorded videotapes were reviewed in the laboratory and analyzed by a computer based imaging software program (Optimas ${ }^{\circledR}$ ). Images were saved under their respective location and titled according to their transect and point (i.e., transect 1 point 5 was titled T15). Saved images (there were 110) were digitized for archival purposes. Each video image was assigned a dominant and sub-dominant substrate class (Table 1) based on long-axis diameter. Dominant substrate was the predominant size class of substrate size based on surface area; sub-dominant was the second-most common size class.

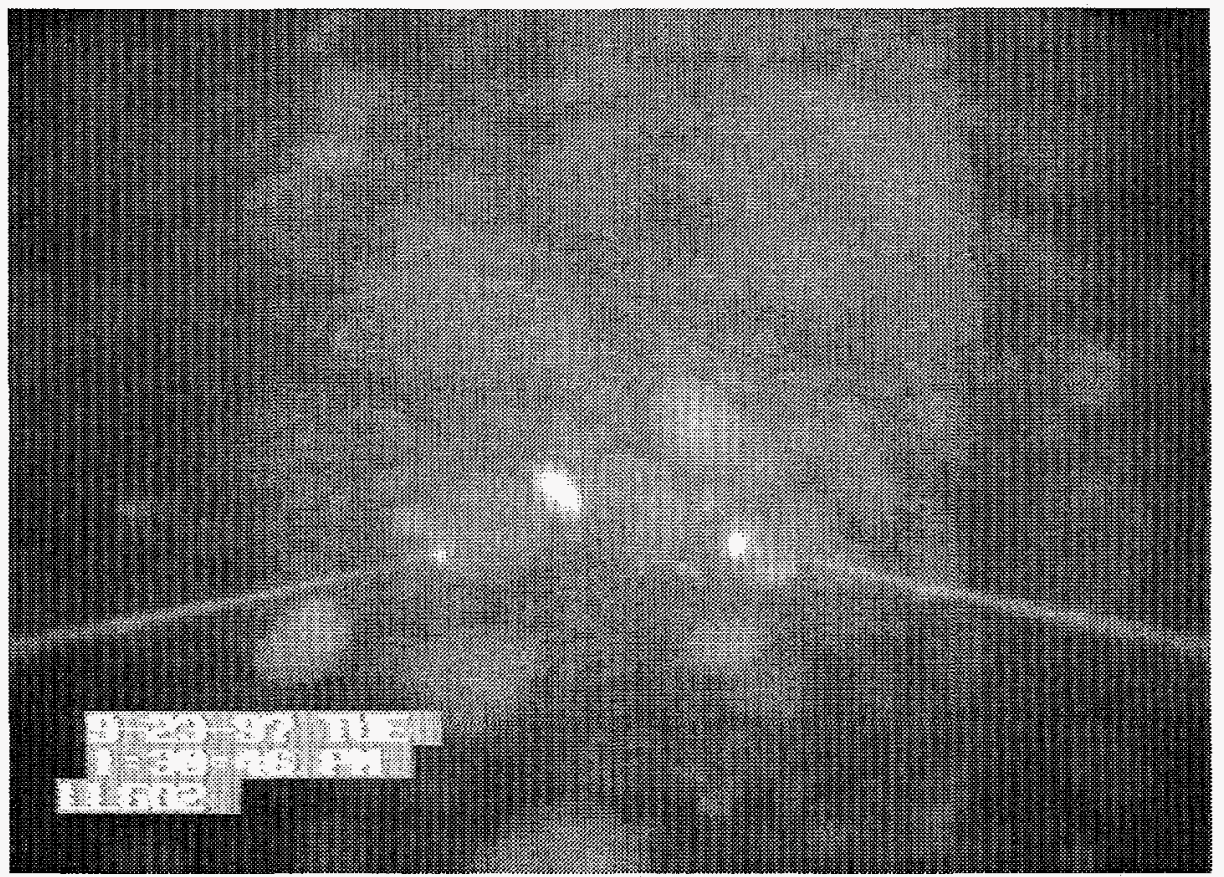

Figure 2. Digitized substrate image showing laser reference markers. Distance between laser points is $18.4 \mathrm{~cm}$. 
Approximately 84 nose velocity measurements were taken using a flow meter (Marsh - McBirney Flow Mate 2000) attached to the diving sled. Velocities were taken at a distance of approximately $0.45 \mathrm{~m}$ above the substratum. Current profiles (average water column velocity and total discharge) were collected using an Acoustic Doppler Current Profiler (ADCP; RDI Instruments Model DRBB-600 $\mathrm{kHz}, 20$ degree).

Table 1. Substrate Categories Used for Spawning Habitat Classification (modified from Platts et al. 1983)

\begin{tabular}{llc}
\hline Category & Sediment classification & $\begin{array}{c}\text { Average particle diameter } \\
\text { size }(\mathrm{cm})\end{array}$ \\
\hline & & \\
1 & Fines, sand, silt, and mud & $<0.6$ \\
2 & Gravel & $0.6-7.6$ \\
3 & Medium cobble & $7.6-15.2$ \\
4 & Large cobble & $15.2-30.5$ \\
5 & Boulder/bedrock & $>30.5$ \\
\hline
\end{tabular}

Spawning habitat polygons were constructed for each of the four physical variables (i.e., depth, nose velocity, dominant substrate, and subdominant substrate) based on the transect data collected during the field surveys. For mapping purposes, categories were created for each of the four variables. Depth categories were 1.5-3.0 m, 3.0-4.6 m, 4.6-6.1 m, and 6.1-6.7 m. Nose velocities were classified into three categories, $0-0.3 \mathrm{~m} / \mathrm{s}, 0.3-0.6 \mathrm{~m} / \mathrm{s}$, and $0.6-0.9 \mathrm{~m} / \mathrm{s}$. Dominant and subdominant substrates were classified according to Table 1. The size of the polygons was estimated by interpolating between sampling point locations (longitudinal and lateral direction) and then smoothing the edges. The boundaries of each polygon were traced and then digitized into the GIS.

To determine if suitable fall chinook salmon spawning habitat conditions existed in the vicinity of the ISRM experiment, the spawning habitat polygons were compared to known spawning habitat. Spawning habitat criteria were based on measurements of depth, velocity, and dominant and subdominant substrate taken on 231 fall chinook salmon redds from the Hanford Reach (Table 2). For velocity and depth, we assumed the range between the $25^{\text {th }}$ and $75^{\text {th }}$ percentile represented preferred spawning habitat. For dominant and subdominant substrate, we used the substrate category found most frequently in Hanford Reach redds. The intersections of spawning habitat polygons that 
contained the characteristics of all our spawning habitat criteria were deemed suitable spawning habitat polygons. All other areas were deemed unsuitable.

Table 2. Preferred Spawning Habitat Criteria for Adult Fall Chinook Salmon (based on unpublished data for Hanford Reach fall chinook salmon, PNNL) and our Corresponding Categories for Dominant and Subdominant Substrate, Nose Velocity, and Depth

\begin{tabular}{lcc}
\hline $\begin{array}{l}\text { Preferred habitat } \\
\text { category }\end{array}$ & Description & Our categories \\
\hline Dominant substrate & 7.6 to $15.2 \mathrm{~cm}$ & Medium cobble \\
Subdominant substrate & 0.6 to $7.6 \mathrm{~cm}$ & Gravel \\
Nose velocity & 0.4 to 1.1 & 0.3 to 0.6 and 0.6 to 0.9 \\
Depth & 1.1 to $3.4 \mathrm{~m}$ & 1.5 to 3.0 and 3.0 to 4.6 \\
\hline
\end{tabular}




\section{Results and Discussion}

No fall chinook salmon redds were found in the survey area during either the aerial or underwater video surveys. The November 1997 aerial surveys documented 210 redds near the island adjacent to the 100-D Area; the closest redd was observed approximately $240 \mathrm{~m}$ downstream of the study site. The location and number of redds in this vicinity was consistent with the previous year's surveys (Dauble and Watson 1997).

The average depth of the study site was $3.9 \mathrm{~m}$ (range 2.1 to $7.0 \mathrm{~m}$ ) while the average velocity was $0.5 \mathrm{~m} / \mathrm{s}$ (range 0.1 to $0.9 \mathrm{~m} / \mathrm{s}$; Figure 3). The river discharge (measured at river kilometer 608) during the November 11 survey ranged from 1,950 to $3,300 \mathrm{~m}^{3} / \mathrm{sec}$ and from 1,950 to $3,400 \mathrm{~m}^{3} / \mathrm{sec}$ on November 13,1997 . These are within the range of daily average discharges during peak spawning (October 26 to November 26) from 1959 to 1985 (1,200 to 3,800 $\mathrm{m}^{3} / \mathrm{sec}$; Dauble and Watson 1997). Thus, at discharges observed during the spawning period, we estimated that approximately $70 \%$ of the study area contained depths in the range suitable for fall chinook salmon spawning, and $90 \%$ of the study area contained preferred velocities of $0.3-0.9 \mathrm{~m} / \mathrm{s}$ (Table 3).

That so much of the study site contained water depth suitable for spawning was not surprising because water depth is typically not a limiting factor to fall chinook salmon spawning in other areas of the Hanford Reach (PNNL, unpublished data). Even though $90 \%$ of the nose velocities were within the range that we have observed on fall chinook salmon redds, values tended toward the low end of the preferred range. For example, the maximum nose velocity within the study area was less than the mean nose velocity measured at redds $(0.9 \mathrm{~m} / \mathrm{s}$; PNNL, unpublished data).

Approximately $67 \%$ of the study area was estimated to have large cobble as the dominant substrate (Figure 3). The substrate category found least often as a dominant substrate was fines ( $2 \%$ of the study area). Approximately $15 \%$ of study area contained medium cobble as the dominant substrate (i.e., the preferred dominant substrate (Table 3 ). Medium cobble was the subdominant substrate found most often ( $48 \%$ of the study area) with large cobble and gravel (the preferred subdominant substrate) each constituting about $20 \%$ of the study area (Table 3 and Figure 3 ).

The relative availability of individual habitat variables was velocity $>$ depth $>$ subdominant substrate $>$ dominant substrate (Table 3 ). When all four variables were combined to generate an estimate of spawning habitat, less than $1 \%$ of the study area adjacent to the ISRM experiment would be considered suitable for fall 
chinook salmon spawning (Table 3). Suitable spawning habitat was patchy and distributed throughout the study area (Figure 4). With the exception of a 1,700 $\mathrm{m}^{2}$ patch near the north shoreline, most of the individual patches were less than $200 \mathrm{~m}^{2}$ in size.

Maps illustrating the distribution of individual parameters, including depth, nose velocities, and substrate classifications, are presented in Appendix A.

Table 3. The Estimated Amounts of Suitable Spawning Habitat for Adult Fall Chinook Salmon Within the Study Site Adjacent to the 100-D ISRM Test Site. The Total Study Area was Estimated to be $315,772 \mathrm{~m}^{2}$.

\begin{tabular}{|c|c|c|}
\hline $\begin{array}{l}\text { Preferred spawning habitat } \\
\text { parameter }\end{array}$ & $\begin{array}{c}\text { Estimated area } \\
\left(\mathrm{m}^{2}\right)\end{array}$ & $\begin{array}{c}\text { Proportion of } \\
\text { total study area } \\
(\%)\end{array}$ \\
\hline \multicolumn{3}{|l|}{ Dominant substrate } \\
\hline $\begin{array}{l}7.6-15.2 \mathrm{~cm} \text { (med. cobble) } \\
\text { Subdominant substrate }\end{array}$ & 45,400 & 14 \\
\hline $\begin{array}{l}0.6-7.6 \mathrm{~cm} \text { (gravel) } \\
\text { Nose velocity }\end{array}$ & 62,550 & 20 \\
\hline $\begin{array}{l}0.3-0.9 \mathrm{~m} / \mathrm{s} \\
\text { Depth }\end{array}$ & 295,600 & 94 \\
\hline $1.5-4.6 m$ & 228,150 & 72 \\
\hline $\begin{array}{l}\text { Polygon overlap } \\
\text { All parameters }\end{array}$ & 2,700 & $<1$ \\
\hline
\end{tabular}

Suitable spawning habitat of fall chinook salmon in large rivers like the Columbia River is usually more limited than suggested by typically measured physical habitat variables (Geist and Dauble, in press). Other factors, like intragravel flow, were suspected to be better descriptors of fall chinook salmon spawning habitat. These data, combined with the small amount of suitable habitat as suggested by this analysis of depth, substrate, and velocity, make it unlikely that a significant number of fall chinook salmon would use this area for spawning. 

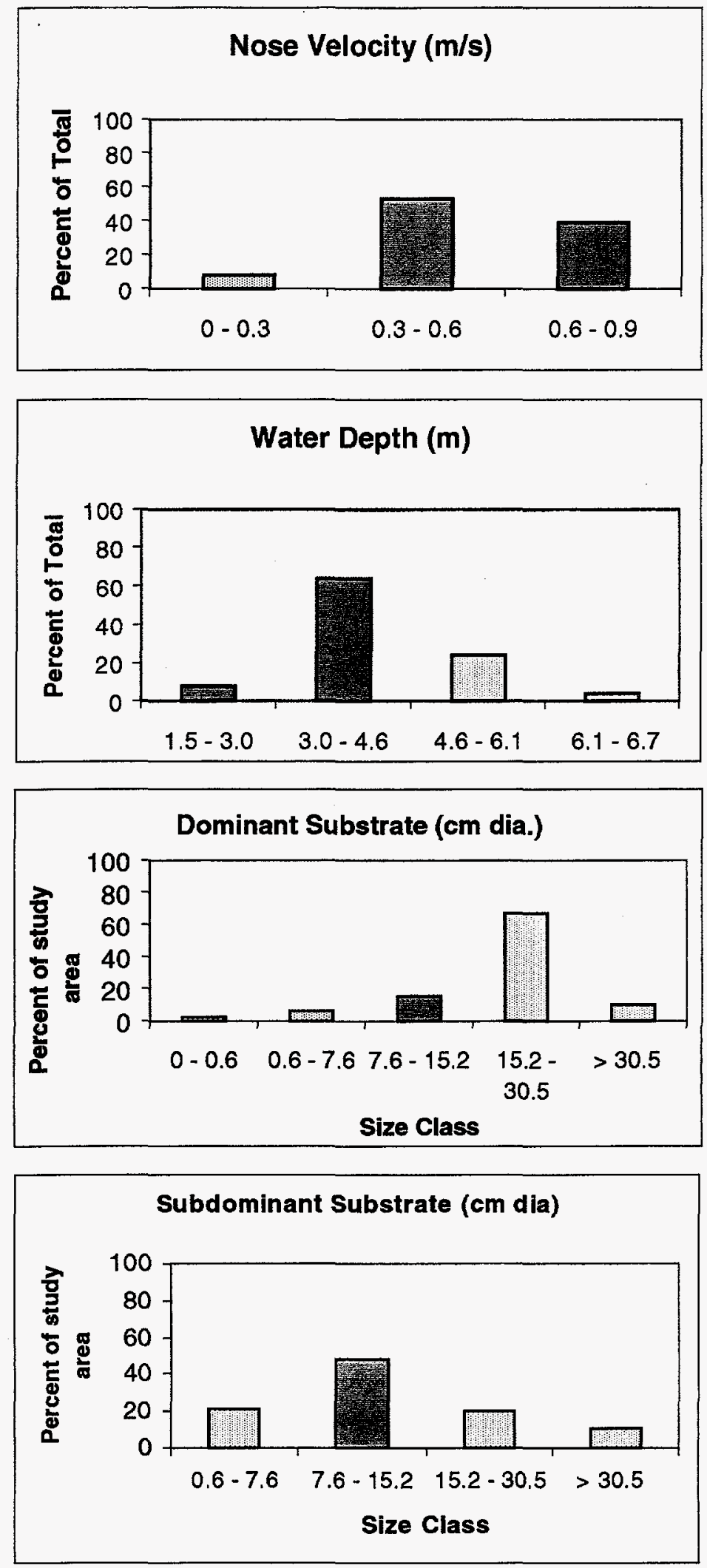

Figure 3. The Distribution Across Categories of Nose Velocities, Depth, Dominant Substrate, and Subdominant Substrate as a Percentage of the Total Study area $\left(315,772 \mathrm{~m}^{2}\right)$ Adjacent to the ISRM Test Site. 


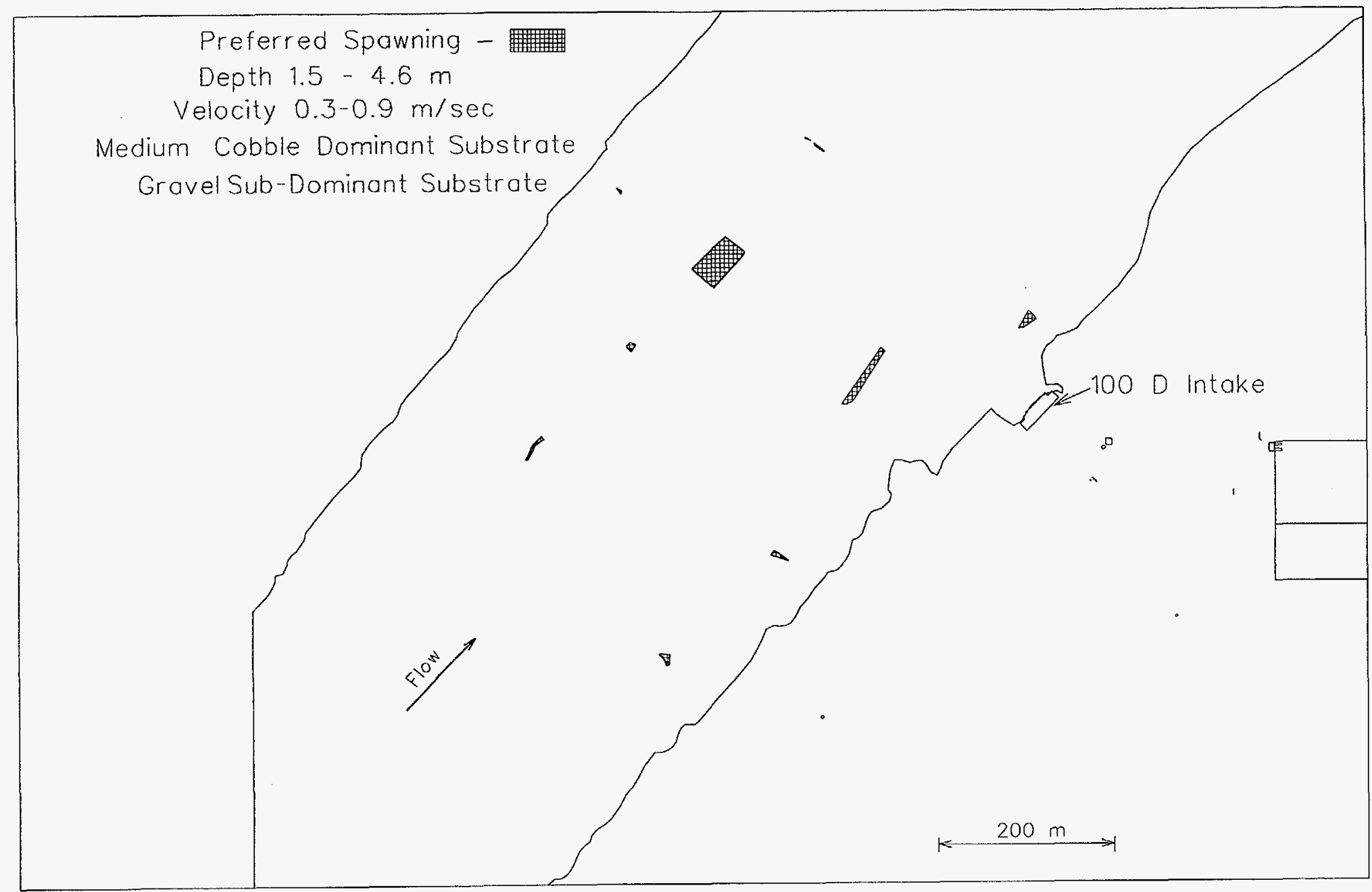

Figure 4. The estimated distribution of suitable spawning habitat for fall chinook salmon at the ISRM test site. 


\section{References}

Dauble, D.D. and D.G. Watson. 1997. Status of fall chinook salmon populations in the mid-Columbia River, 1948-1992. North American Journal of Fisheries Management 17: 283-300.

Dauble, D.D., R.L. Johnson, R.P. Mueller, C.S. Abernethy, B.J. Evans, and D.R. Geist. 1994. Identification of Fall Chinook Salmon Spawning sites Near Lower Snake River Hydroelectric Projects. Prepared for U.S. Army Corps of Engineers, Walla Walla District, Walla Walla, Washington by Pacific Northwest Laboratory, Richland, Washington.

Dauble, D.D., R.L. Johnson, R.P. Mueller, and C.S. Abernethy. 1995. Spawning of Fall Chinook Salmon Downstream of Lower Snake River Hydroelectric Projects 1994. Prepared for U.S. Army Corps of Engineers, Walla Walla District. Walla Walla, Washington by Pacific Northwest Laboratory, Richland, Washington.

Geist, D.R. 1995. The Hanford Reach: What do we Stand to Lose? Illahee 2:130-141.

Geist, D.R., and D.D. Dauble. In press. Redd site selection and spawning habitat use by fall chinook salmon: the importance of geomorphic features in large rivers. Environmental Management.

Geist, D.R., T.M. Poston, and D.D. Dauble. 1994. Assessment of Potential Impacts of Major Groundwater Contaminants to Fall Chinook Salmon in the Hanford Reach, Columbia River. PNL-9990, UC-600. Pacific Northwest National Laboratory, Richland, Washington.

Huntington, C.S., W. Nehlsen, and J. Bowers. 1996. A survey of Healthy Native Stocks of Anadromous Salmonids in the Pacific Northwest and California.

Fisheries 21(3):6-14.

Platts W.S., W.F. Megahan, and G.W. Minshall. 1983. Methods for evaluating stream, riparian, and biotic conditions. U.S Forest Service Technical report INT. 138.

U.S. Environmental Protection Agency (EPA). 1986. EPA 440/5-86-001. Office of Water Regulations and Standards, Washington, D.C. 


\section{Appendix A}

Maps Illustrating Habitat Variables Measured Near the ISRM 100-D Reactor Treatability Site 


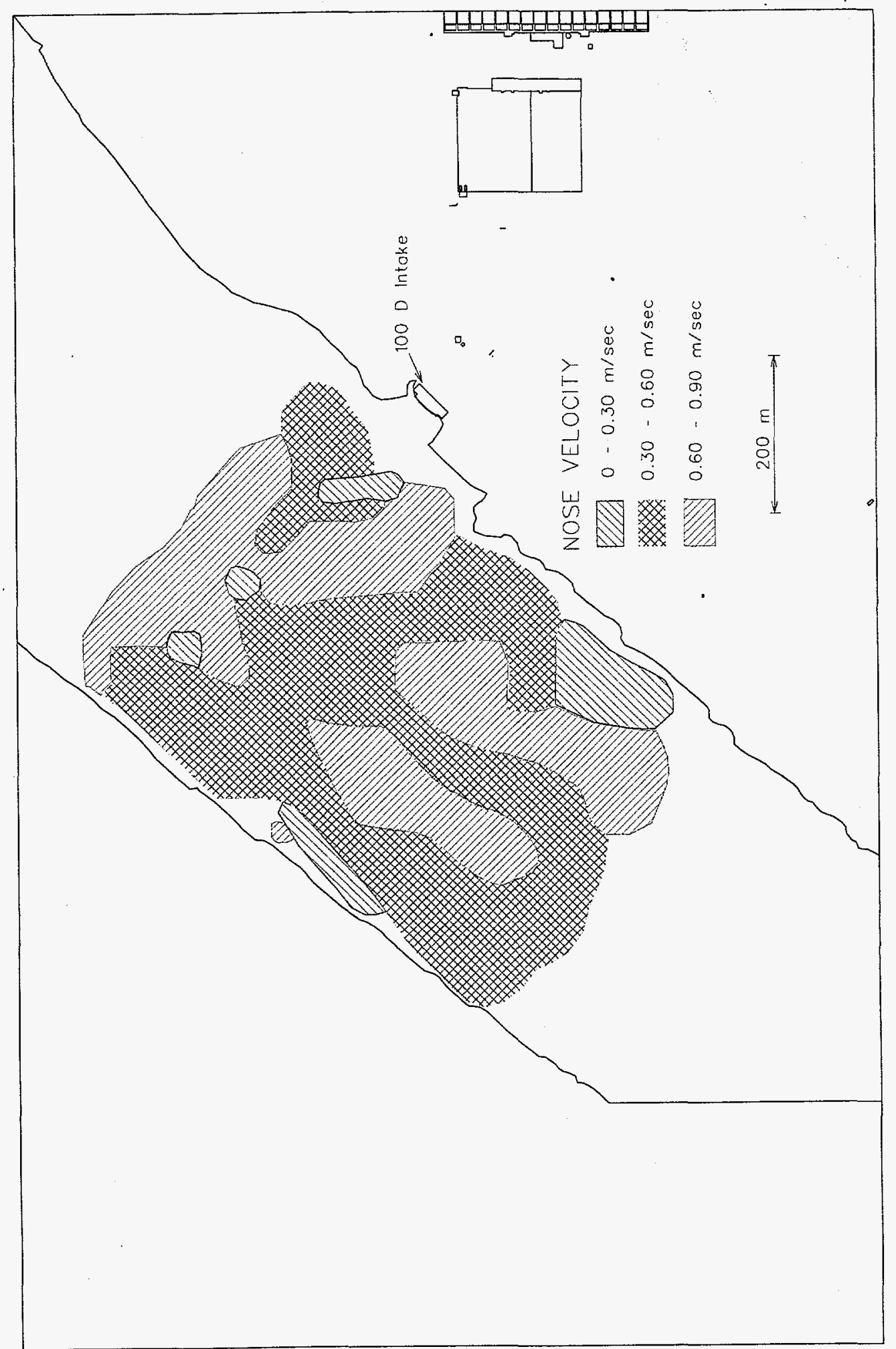

A. 1 


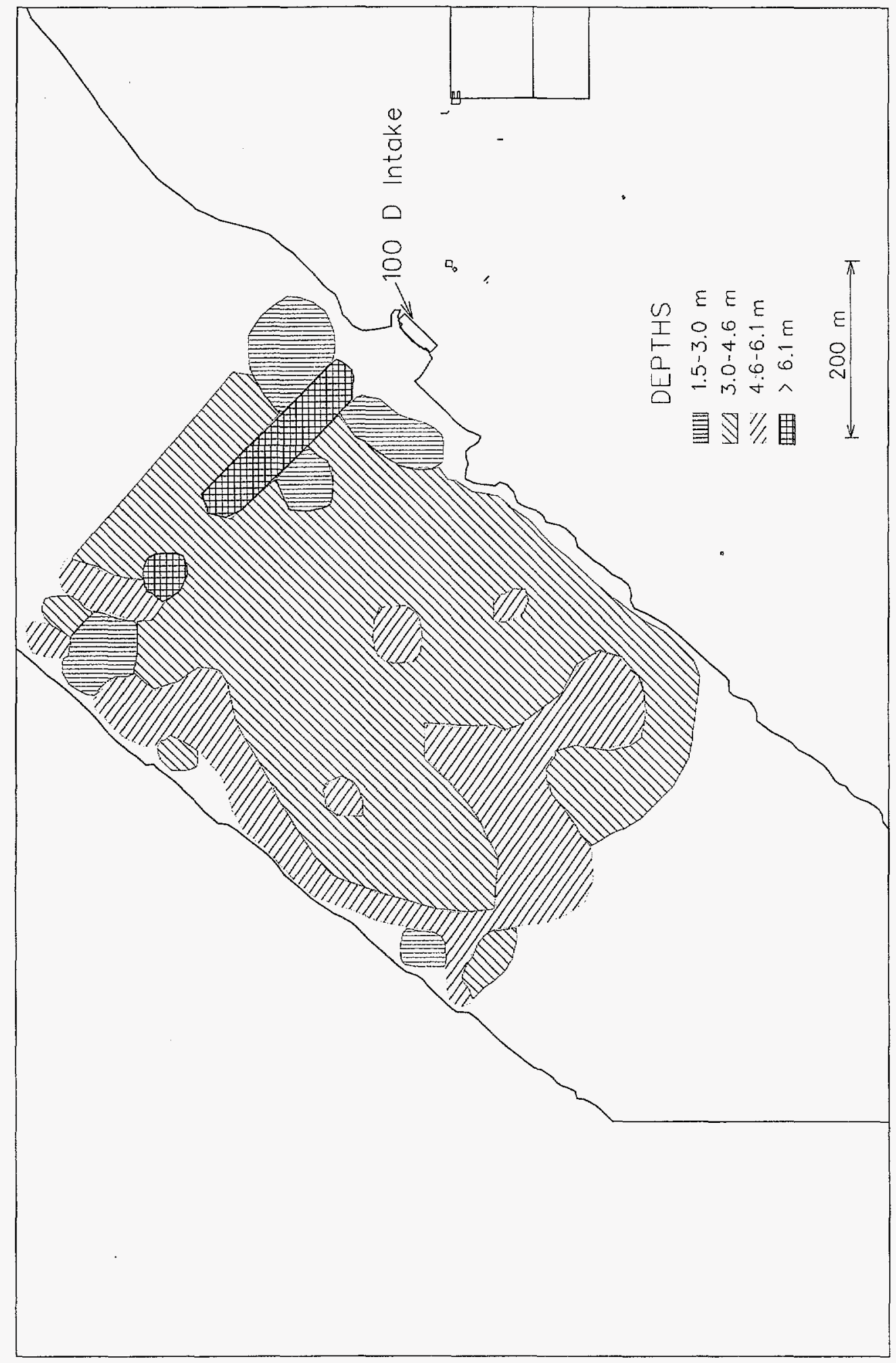

A.2 


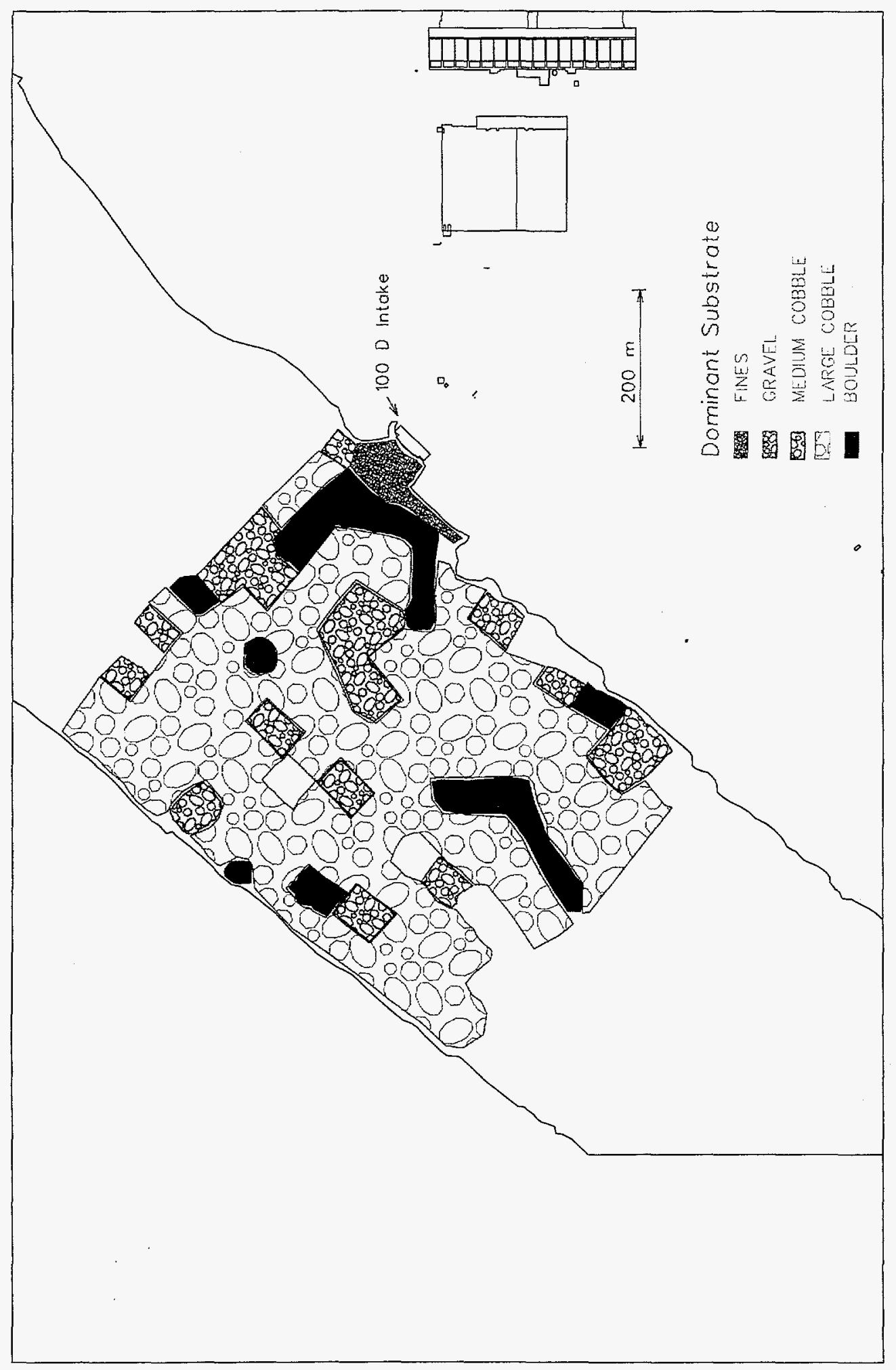




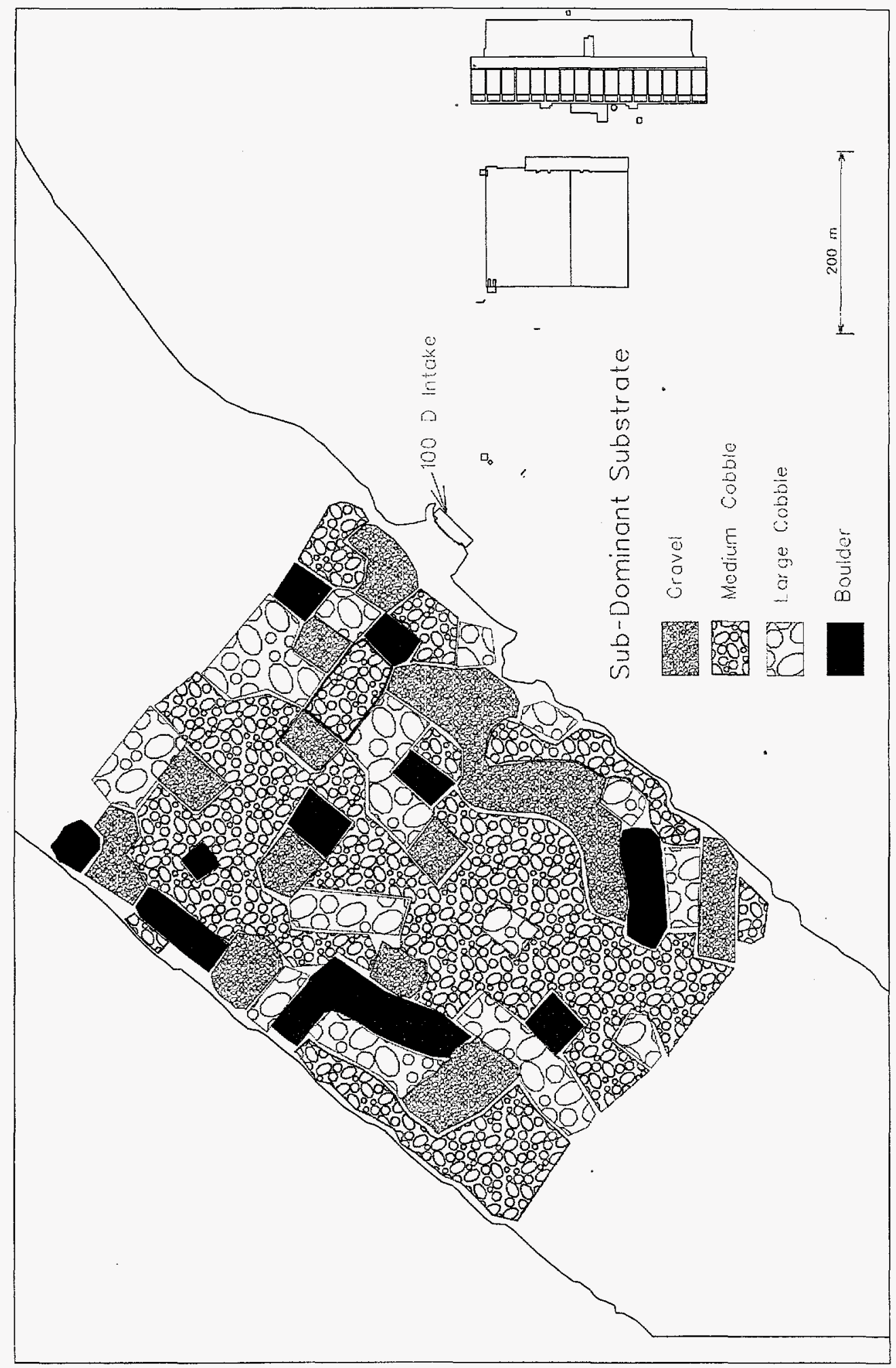

A.4 


\section{Distribution}

No. Of

Copies

\section{OFFSITE}

Grover Chamberlain, EM-54

U.S. Department of Energy

Office of Science and Technology

Cloverleaf Building

2400 Century Blvd.

Germantown, MD 20874

Barbara Harper

Yakama Indian Nation

P.O. Box 151

Toppenish, WA 98984

Tom Engle, $\mathrm{HAB}$

Department of Civil Engineering

University of Washington

Seattle, WA 98185

Stuart Harris

Confederated Tribes of the Umatilla Indian Reservation

P.O. Box 638

Pendleton, OR 97801

Donna L. Powaukee

Nez Perce Tribe

ERWM Manager

P.O. Box 365

Lapwai, ID 83540-0365

Philip Washer, DOE-SR

U.S. Department of Energy

Savannah River Operations Office

RFD \#1, Bldg. 703A,

Rm E208 North

P.O. Box A

Aiken, SC 29802
No. Of

Copies

James A. Wright, DOE-SR

U.S. Department of Energy

Savannah River Operations Office RFD \#1, Bldg. 703A,

Rm E208 North

P.O. Box A

Aiken, SC 29802

\section{ONSITE}

7 DOE Richland Operations Office

D.L. Biancosino

J.P. Hanson

R.M. Rosselli

K.M. Thompson

A.C. Tortoso

F.R. Serier

J.P. Neath

3 Bechtel Hanford, Inc.

G.C. Henckel

M.A. Buckmaster

J.G. April

3 U.S. Environmental Protection Agency

D.A. Faulk

L.E. Gadbois

D.R. Sherwood

3 Washington Department of Ecology

D.N. Goswami

W.W. Soper

N.H. Uziemblo 
Washington Department of Fish

and Wildife

J.L. McConnaughey

37 Pacific Northwest National Laboratory
C.L. Blair
C.R. Cole
J.L. Devary
R.M. Ecker
J.S. Fruchter (10)
D.R. Geist
W.J. Martin
R.P. Mueller (10)
J.E. Szecsody
S.S. Teel
V.R. Vermeul
M.D. Williams
Information Release (7)

Distr. 2 